(экономистами, управленцами, менеджерами) в нашей стране и за рубежом.

Важное правило, которому необходимо следовать при переводе и подборе эквивалентов, состоит в том, что переводу подлежат не слова, а понятия. При сопоставлении, прежде чем отождествлять термины двух разных языков, нужно уяснить, какое явление или предмет они представляют. Это относится не только к тождественным понятиям, но даже скорее к понятиям, не имеющих эквивалентов в других языках. В данном случае невозможно механически перенести формы выражения языка оригинала на другой язык [5, с. 5].

Ознакомление не только с отечественной, но и с зарубежной переводческой практикой в различных областях науки и техники позволяет лучше осознать задачи переводчика терминологии школы. Так, согласно докладу комитета Лондонского института лингвистики, переводчик должен отвечать следующим требованиям: широко знать все аспекты предмета, а также сочетаемость слов, иметь хорошо развитые навыки работы над терминологией; привлекать специалистов, представляющих различные профессиональные области предметников и лингвистов [4, с. 60].

Перевод терминологии, в данном случаи терминология школ представляет собой не просто механическую подстановку эквивалентов лексики терминов по словарю, поскольку фактически лишь незначительное число терминов имеет точный эквивалент в другом языке. Удовлетворительный перевод терминов и их определений может осуществить только специалист, имеющий необходимые знания в областях, касающихся деятельности системы образования, в частности высшей школы.

Все это предъявляет весьма строгие требования к уровню профессиональных знаний и опыту специалиста, занимающегося переводом. Подобные требования объясняются тем, что в различных странах существует различная практика. Для адекватного перевода требуется знания о состоянии и развитии соответствующей предметной области.

Что касается зарубежных систем образования, то здесь требуется не только перевод в обычном смысле этого слова, но и осмысление характера связей и отношений, существующих в национальных системах высшего образования стран.

Перевод понятий, отражающих особые явления или события, требует профессиональных знаний реалий и истории развития школьного образования.

\section{Список литературы:}

1. Верещагин Е. М. Костомаров В. Г. Лингвострановедческая теория слова. М., 1983. - 320 с.

2. Елизарова Г. В. Культурологическая лингвистика. опыт исследования понятия в методических целях. СПб.: Бельведер, 2012. - 140с.

3. Емельянова Я. Б. Лингвострановедческая компетенция переводчика: теория и практика. Н. Новгород: ООО "Стимул-СТ", 2010. - 210 с.

4. Таранова Н. В. Лингвокультурологический аспект значения отглагольных имен. // Лексическая системность английского языка в культурологическом ракурсе (семантика и функционирование). Вестн. Моск. гос. лингвист. ун-та; вып. 537. Сер. Лингвистика. - М.: Рема, 2007. - С. 6070 .

5. Таранова Н. В. Отглагольные имена существительные как средство номинации в современном английском языке. Дисс кандидата филологических наук. М., 2008

6. Таранова Н. В. Социокультурологическая роль переводчика. // «Социолингвистические и культурологические проблемы изучения русского языка и русской литературы в контексте диалога культур». Магнитогорск: Издательство МГТУ им. Г.И. Носова, 2004. - С. 148 - 149.

7. Тер - Минасова С. Г. Язык и межкультурная коммуникация. М.: Слово, 2000. - 264 с.

\title{
ОБРАЗ ЗЕРКАЛА В МИФАХ И ЛИТЕРАТУРЕ ЯПОНИИ
}

Толубанова Оксана Игоревна

студентка СахГУ, г. Южно-Сахалинск

DOI: 10.31618/ESU.2413-9335.2019.5.58.66-68

\section{АННОТАЦИЯ}

Путем изучения мифов и литературы Японии, была поставлена цель выявить особенности образа зеркала. В качестве литературных источников выступали древние японские письменные памятники «Записи о деяниях древности» и «Японская летопись», мифы и сказки.

\section{ABSTRACT}

By studying the myths and literature of Japan, the goal was set to reveal the features of imagery of the mirror. The ancient Japanese written monuments "Records of Ancient Matters" and "The Chronicles of Japan", myths and tales acted as literary sources.

Ключевые слова: образ зеркала, характеристики зеркала, японские мифы, японская литература.

Keywords: imagery of the mirror, mirror characteristics, Japanese myths, Japanese literature.

Образ зеркала присутствует и в мифологии, и в литературе этой страны. Помимо 古事記 Кодзики «Записей о деяниях древности», образ зеркала можно встретить в 日本書紀Нихон сёки «Японской летописи», 大鏡 О:кагами «Великое зерцало», в рассказе «Колокол из Мугэна», в предании о великом японском скульпторе «Хидари Дзингоро»и в японской народной сказке «Зеркало Мацуямы». 
Одна из регалий императора Японии, Божественное Зеркало, имеет мифологическое происхождение. В 古事記Кодзики «Записях о деяниях древности» и 日本書紀 Нихон сёки «Японской летописи» говорится, что天照大神 Аматэрасу о:ками «великая богиня, озаряющая небеса», обидевшись на своего брата, бога ветра 須佐之男命尊 Сусаново-но микото «смелый быстрый бог-мужчина из Суса», за его оскорбительные поступки по отношению к ней, спряталась в пещеpe. В тот миг мир покрылся мраком. Другие божества были опечалены уходом богини солнца и решили выманить ее из укрытия. Для этого Ама-но арато, дальнему предку рода зеркальщиков, было приказано создать зеркало [4, с. 137]. Оно помогло божествам вернуть богиню солнца. Позже она передала этот предмет своему внуку 瓊瓊杵尊 $\mathrm{Huни-}$ ги-но микото «бог рисового урожая», родоначальнику императорского дома, сказав: «Пусть мой внук смотрит на это зеркало, как будто бы это я сама было. И пусть он славит это зеркало, поместив его с собой на одном полу, в одной обители» [4, c. $157-158]$.

О божественном происхождении данного предмета в своем кратком очерке «Божественное зерцало» историк Х. Дэвис писал: «Зеркало символизирует человеческое сердце, которое, будучи чистым и спокойным, отражает образ самого бога» [1, с. 181]. Следует упомянуть, что мифология Японии содержит описание божеств, возникновение островов и народа Японии, таким образом отражая основу японской религии - 神道синто «путь богов». Что, в свою очередь, дает зеркалу религиозное значение.

Кроме того, понятие «зерцало» обозначает власть и передачу власти в японской культуре. В Кодзики говорится: «Узнаем мы о том, что прикреплено было зерцало и выплюнуты яшмы; и что наследовали друг другу сотни царей...» [2, с. 30]. Так как император считается потомком богини солнца Аматэрасу, зерцало впоследствии стало олицетворением императорской власти, одной из трех регалий необходимой для вступления в права наследования новому императору. Оно также является реликвией синтоистского святилища Исэ, хранящимся вместе с мечом и яшмовым ожерельем, образуя три регалии императора, доказывающих божественное происхождение рода.

Можно предположить, что поверье о том, что зеркало хранит в себе душу своего владельца, появилось из мифов. Поэтому японцы не продают свои зеркала, им это даже в голову не придет, ведь новый хозяин может навредить душе в зеркале или оно само может быть проклятым.

В преданиях, жанре фольклорной несказочной прозы, описывающем историю и исторические личности, также можно встретить образ зеркала. Так, в предании «Хидари Дзингоро» говорится о легендарном японском скульпторе, который с первого взгляда влюбился в проходящую мимо женщину. Ее красота настолько ошеломила мужчину, что он сразу же вернулся в свою мастерскую и принялся ваять скульптуру по ее образу. К счастью мастера, во время случайной встречи с той незнакомкой, она обронила зеркало, которое он бессознательно подобрал. Скульптор разместил его между высеченными складками одежды скульптуры. И статуя ожила, так как зеркальце изза частого использования красавицей хранило часть ее души. Мастер был вне себя от радости, что может быть вместе со своей возлюбленной. Это предание содержит древнее верование японцев о свойстве зеркала вбирать душу хозяина.

Образ зеркала также присутствует в японском фольклорном - 怪談 кайдане «устном рассказе о сверхъестественном». Истории подобного жанра создавались чтобы испугать слушателей, поведав о мистических событиях, столкновениях с привидениями и демонами, другой нечистью. Зеркало является центральным образом в кайдане «Колокол из Мугэна».

В рассказе «Колокол из Мугэна» речь идет о женщине из деревни Мугэн-ни-яма, пожертвовавшей храму зеркало, которое передавалось из поколения в поколение по женской линии. Вскоре после этого японку начали мучить сомнения. Каждый день она вспоминала его и думала «сколько счастливых улыбок отражалось в полированной бронзе» [3, с. 71], повторяя поговорку: «Зеркало душа женщины», полная версия которой выглядит так: «Меч - душа самурая, зеркало - душа женщины. / Затуманилось зеркало - значит, душа нечиста».

Когда собрали нужное количество зеркал чтобы создать колокол, монахи отправили их мастерам на переплавку. Литейщики не смогли расплавить одно единственное зеркало. Тогда все поняли, что кто-то сделал подношение не от чистого сердца, и к зеркалу был привязан жадный дух, не позволявший его расплавить. Слухи сразу же разлетелись и всем стало известно, чье это зеркальце. Женщина, замученная стыдом, покончила с собой. И ее дар, наконец, расплавился.

После ее смерти нашли записку: «Тому, кто сумеет разбить колокол, мой дух дарует огромное богатство» [3, с. 73]. Все дело в том, что дух умершего из-за самоубийства или в ярости и злобе получает сверхъестественную силу. Поэтому местные, вспоминая ее прощальное письмо, ежедневного посещали святилище чтобы позвонить в колокол. Он стойко выдерживал бурный поток желающих, но служителям не хватило выдержки выслушивать вечный звон, и они выбросили его в топь.

Поверье о том, что после смерти человека в зеркале остается его душа, содержится и в народной сказке «Зеркало Мацуямы». В местечке Мацуяма жили семейная пара с маленькой дочкой. Однажды муж уехал в столицу Киото по делам, откуда вернулся с подарками. Дочке он подарил куклу, а жене - зеркало. У жены, выросшей в глухой деревушке, этот предмет вызвал удивление, так как до этого дня ничего подобного ей видеть не приходилось. Ей казалось, что она видит в зеркале кого-то неизвестного. Мужчина объяснил супруге, 
что «в него можно смотреться» и попросил бережно с ним обращаться.

Спустя какое-то время его супруга смертельно заболела. Умирая, она сказала дочери следующее: «Возьми это зеркало и, когда тебе будет очень одиноко, посмотрись в него, и ты всегда сможешь увидеть меня» [1, с. 186].

Отец вновь женился. Мачеха невзлюбила девочку, поэтому она часто пряталась и смотрела в зеркальце. Однажды, ее заметила мачеха и, толком не разглядев чем та занята, подумала, что она сделала проклятую куклу чтобы изжить новую супругу отца. Мачеха сразу же обратилась к мужу, обвинив падчерица в колдовстве.

Мужчина поверил ей и, придя в ярость, начал стыдить дочь. Отрицая все обвинения, девочка показала отцу зеркало, рассказала о последних словах матери и добавила: «Когда у меня на сердце тяжесть, я беру зеркало, и мамино лицо с милой доброй улыбкой приносит мне утешение и помогает выносить грубые слова и косые взгляды» [1, с. 187]. Осознав, что оказался неправ, отец помирился с ней, а мачеха устыдилась и попросила прощенье.

Сюжет данной сказки перекликается с мыслью одного известного средневекового автора. Дама, жившая при императорском дворе в эпоху Хэйан (кон. VIII - нач. XII вв.), 清少納言 СэйСёнагон, в своих 枕草子 макура-но сё:си «Записках у изголовья» писала: «Когда горный фазан тоскует по своей подруге, говорят, он утешится, обманутый, если увидит свое отражение в зеркале» [7, с. 61]. Здесь, писательница показывает читателю, что человек может увидеть в отражении близкого ему человека, и таким образом, хоть и вводя себя в заблуждение, обретет душевный покой.

Ввиду того, что с зеркалами связано большое количество обычаев, суеверий и верований, писатели любят использовать их. В средневековом историческом повествовании, написанном примерно в конце эпохи Хэйан (кон. VIII - нач. XII вв.), 大鏡O:кагами «Великое зерцало» повествование ведется от имени двух старцев Сигэки и Ёцуги. Являясь рассказчиками, они повествуют о многих влиятельных лицах и их окружении. Из этого произведения можно узнать о жизни императоров, министров, чиновников и других.

В сочинении О:кагами «Великом зерцале» образ зеркала является центральным и содержит мысль о смене поколений, памяти рода. Оно отра- жает людские судьбы, показывает истину, суть всех событий и природу людей. Старцы упоминают два типа зеркал: магическое и «пустое зеркало». Магическое зерцало сравнивается с душой, которая сохраняет в себе события и людей, а «пустое» - это предмет, который использовали как бытовой предмет.

Сигэки, отождествляя свой рассказ со всезнающим зеркалом, сложил об этом следующую 和歌 вака «японскую песнь»:

Перед светлым зеркалом

Все, что минуло,

Что есть сейчас

И что грядет,

Прозреваю! [6, с. 34].

Образ зеркала в культуре Японии прошел длинный путь. Развиваясь вместе с японским обществом он упоминался в мифах, легендах, древних письменных источниках и литературе разных эпох. Приобретая значения бытового предмета, религиозной реликвии императорского дома, входа в потусторонний мир, вместилища душ, хранителя истории.

Список литературы:

1. Дэвис Х. Мифы и легенды Японии / Пер. с англ. О.Д. Сидоровой. - М.: ЗАО Центрполиграф, 2008. - 379 с.

2. Кодзики - Записи о деяниях древности / Пер., коммент. Е.М. Пинус. - СПб.: ШАР, 1993. 320.

3. Лафкадио Хирн. Призраки и чудеса в старинных японских сказаниях. Кайданы / Пер. с англ. О.А. Павловской. - М.: ЗАО Центрполиграф, 2017. -255 c.

4. Нихон сёки. Анналы Японии: В 2 т. / Пер. и коммент. Л. М. Ермаковой и А. Н. Мещерякова. T. 1. Свитки I-XVI. - СПб.: Гиперион, 1997. - 496 c.

5. Нихон сёки. Анналы Японии: В 2 т. / Пер. и коммент. Л. М. Ермаковой и А. Н. Мещерякова. T. 1. Свитки XVII-XXX. - СПб.: Гиперион, 1997. $432 \mathrm{c}$.

6. О:кагами - Великое Зерцало. / Пер. с яп. Е. М. Дьяконовой. - Спб.: Гиперион, 2000. - 119 с.

7. Сэй Сёнагон. Записки у изголовья / Пер. со старояп. В. Марковой. - СПб.: ООО Издательство «Пальмира»; М.: «Книга по Требованию», 2018. -352 c. 